\title{
PEMBERIAN ASI PADA ANAK DALAM PERSPEKTIF AL-QUR'AN
}

\author{
Asnawati $^{1}$, Ibrahim Bafadhol ${ }^{2}$, Ade Wahidin ${ }^{3}$ \\ ${ }^{1}$ Alumni STAI Al-Hidayah Bogor, \\ ${ }^{2,3}$ Dosen Prodi Ilmu Al-Qur'an dan Tafsir STAI Al Hidayah Bogor \\ email:minumar69@gmail.com
}

Received: 05/05/2019, Accepted: 07/05/2019, Published: 09/05/2019

\begin{abstract}
Breastfeeding is one of the first steps for a human being to get a healthy and prosperous life, but some mothers misunderstand that milk available in the market is better than their own milk. This research is library research using thematic interpretation method and making the Qur'an and its translation as primary sources and completing them with secondary sources taken from the commentary, hadith books, and scientific books that have relevance to the discussion. In the Qur'an God has confirmed the continuity of this breastfeeding for two full years. This two-year period is a time span of gold in terms of health and psychological aspects for babies, which is contained in Q.S. Al-Baqarah [2]: 233, Q.S. Luqman [31]: 14 and Q.S. Al-Ahqaf [46]: 15. Giving breast milk plays an important role in fulfilling baby nutrition so that it can increase the baby's immunity. With breastfeeding can prevent $1 / 3$ the incidence of upper respiratory infections (ARI), the incidence of diarrhea can decrease by $50 \%$ and severe intestinal disease in premature infants can be reduced by $58 \%$ while in mothers, the risk of breast cancer can also decrease by 6-10\%.
\end{abstract}

Keyword: asi, tafseer, Ibnu Kathir

\begin{abstract}
ABSTRAK
Menyusui merupakan salah satu langkah pertama bagi seorang manusia untuk mendapatkan kehidupan yang sehat dan sejahtera, namun sebagian ibu salah memahami bahwa susu-susu yang tersedia di pasar lebih bagus daripada air susu mereka sendiri. Penelitian ini merupakan penelitian kepustakaan dengan menggunakan metode tafsir tematis dan menjadikan Al-Qur`an dan terjemahnya sebagai sumber primer dan melengkapinya dengan sumber sekunder yang diambil dari kitab tafsir, kitab-kitab hadits, dan buku-buku ilmiah yang memiliki relevansi dengan pembahasan. Dalam Al-Qur'an Allah telah menegaskan kelangsungan penyusuan ini selama dua tahun penuh. Masa dua tahun ini merupakan rentang waktu emas ditinjau dari segala sisi kesehatan dan kejiwaan bagi bayi, yakni terdapat dalam Q.S. Al-Baqarah [2]: 233, Luqman [31]: 14, dan Al-Ahqaf [46]: 15. Pemberian ASI sangat berperan dalam pemenuhan nutrisi bayi sehingga dapat meningkatkan kekebalan tubuh bayi. Dengan menyusui dapat mencegah $1 / 3$ kejadian infeksi saluran pernapasan atas (ISPA), kejadian diare dapat turun $50 \%$ dan penyakit usus parah pada bayi premature dapat berkurang kejadiannya sebanyak 58\% sedangkan pada ibu, resiko kanker payudara juga dapat menurun 6-10\%.
\end{abstract}




\section{A. PENDAhuluan}

Sehubungan dengan Sustainable Development Goals (SDGs) atau tujuan pembangunan berkelanjutan 2030, menyusui merupakan salah satu langkah pertama bagi seorang manusia untuk mendapatkan kehidupan yang sehat dan sejahtera. ${ }^{1}$ Pemberian ASI (Air Susu Ibu) harus terus dilakukan sampai bayi berumur dua tahun atau, ${ }^{2}$ namun sebagian ibu salah memahami bahwa susu-susu yang tersedia di pasar lebih bagus daripada air susu mereka sendiri. Mereka banyak memberikan susu buatan pabrik kepada bayi mereka karena sebagian dari mereka ada yang terlalu sibuk dengan karirnya. ${ }^{3}$

Seorang ibu yang sedang bekerja banyak menghabiskan waktu selama delapan jam, hal ini berdampak ibu tersebut tidak memiliki waktu yang cukup untuk menyusui anaknya. Bahkan ditempat kerja para wanita minim kesempatan untuk memerah ASI. Sedangkan jumlah angkatan kerja kaum wanita terus meningkat setiap tahunnya.

1 Siti Rahyhani Fadhila et al. (2016). Dampak dari Tidak Menyusui di Indonesia. Jakarta: Ikatan Dokter Anak Indonesia: Indonesian Pediatric Society; Commited in Improving the Health of Indonesian Children.

${ }^{2}$ Riskesdas. (2016). Situasi Balita Pendek. KemenKes RI. hlm. 2.

${ }^{3}$ Adil bin Yusuf Al-Azzazi. (2008). Saat Ibu Mengandung. Surakarta: Ziyad Books. hlm. 190.
Pada tahun 2013 jumlah pekerja perempuan mencapai 43,3 juta jiwa (38\%) dari 114 juta jiwa. ${ }^{4}$ Padahal kewajiban kaum wanita dalam keluarga tidak hanya berperan sebagai istri namun juga sebagai seorang ibu. Kewajiban yang paling mendasar bagi seorang ibu adalah menyusui (arrada'ah) untuk anak-anaknya. Hal tersebut merupakan hak pertama bagi anak pada ibunya. Hal tersebut sudah termaktub dalam (Q.S. Luqman [31]: 14).

Menurut Riskesdas $2016^{5}$ selama kehamilan dan 730 hari pertama setelah bayi yang dilahirkan telah dibuktikan secara ilmiah merupakan periode yang menentukan kualitas kehidupan. Oleh karena itu periode ini ada yang menyebutnya sebagai "Periode emas (golden age)". Dampak buruk yang dapat ditimbulkan oleh masalah gizi pada periode tersebut, dalam jangka pendek adalah terganggunya perkembangan otak, kecerdasan, gangguan pertumbuhan fisik, dan gangguan metabolisme dalam tubuh. Sedangkan dalam jangka panjang akibat buruk yang dapat ditimbulkan adalah menurunnya kemampuan kognitif dan

\footnotetext{
${ }^{4}$ Kemenkes. (2015). Dukung Ibu Bekerja Beri ASI Eksklusif. Jakarta.

${ }^{5}$ Riskesdas. (2016). hlm. 2.
} 
prestasi belajar, menurunnya kekebalan tubuh sehingga mudah sakit dan resiko tinggi untuk munculnya penyakit diabetes, kegemukan, penyakit jantung, dan kanker.

Hasil Riset Kesehatan Dasar (Riskesdas, 2016) mengenai persentase status gizi balita pendek di Indonesia tahun 2013 adalah 37,2\%, jika dibandingkan tahun $2010(35,6 \%)$ dan tahun 2007 (36,8\%) tidak menunjukkan penurunan atau perbaikan yang signifikan. Masalah balita pendek tersebut menggambarkan adanya masalah gizi kronis, salah satunya dipengaruhi oleh masa pemberian ASI (Air Susu Ibu) pada bayi tersebut yang belum optimal. ${ }^{6}$

Pemberian ASI sangat berperan dalam pemenuhan nutrisi bayi sehingga dapat meningkatkan kekebalan tubuh bayi $^{7}$. Dengan menyusui dapat mencegah 1/3 kejadian infeksi saluran pernapasan atas (ISPA), kejadian diare dapat turun $50 \%$, dan penyakit usus parah pada bayi premature dapat berkurang kejadiannya sebanyak 58\% sedangkan pada ibu, resiko kanker payudara juga dapat menurun $6-10 \%{ }^{8}$

${ }_{7}^{6}$ Riskesdas. (2016). hlm. 1-3.

${ }^{7}$ Riskesdas. (2016). hlm. 6.

8 Siti Rahyhani Fadhila et al. (2016). Dampak dari Tidak Menyusui di Indonesia. Jakarta.
Allah telah menegaskan kelangsungan penyusuan ini selama dua tahun penuh ${ }^{9} .{ }^{10}$ Masa dua tahun ini merupakan rentang waktu emas ditinjau dari segala sisi kesehatan dan kejiwaan bagi bayi. Allah Subhanahu Wata"ala telah memberikan informasi tersebut dalam wahyu-Nya yang suci dan agung yakni terdapat dalam Q.S. Al-Baqarah [2]: 233, Luqman [31]: 14, dan AlAhqaf [46]: 15. Dari latar belakang ini maka tulisan ini akan mengkaji tentang Bagaimana konsep ar-rada'ah (pemberian ASI) dalam perspektif AlQur’an

\section{B. KAJIAN PUSTAKA}

Penyusuan atau yang sudah dikenal sebagai pemberian ASI eksklusif adalah pemberian hanya ASI tanpa memberikan cairan atau makanan padat lainnya kecuali vitamin, mineral, atau obat dalam bentuk sirup sampai usia 4-6 bulan. $^{10}$

Manfaat umum pemberian ASI kepada bayi adalah membuat bayi tumbuh dengan sehat jasmani ruhani dan mentalnya. Manfaat bagi ibu antara

\footnotetext{
${ }^{9}$ Wafae $^{\text {ee }}$ Binti Abdul Aziz As-Suwailim. (2013). Fikih Ummahat: Himpunan Hukum Islam Khusus Ibu. Jakarta Timur: Ummul Qura. hlm. 257.

10 World Health Organization. (1998). Complementary Feeding of Young Children in Developing Countries: a review of Current scientific knowledge. Geneva: WHO.
} 
lain: menyusui menjadi metode alami kontrasepsi selama 6 bulan pertama, terhindar dari kanker payudara, perdarahan tipe lambat berkurang, membantu pengecilan rahim. Manfaat bagi keluarga: ekonomis, hygenis, praktis dan bahagia. Manfaat bagi negara: menurunkan angka kesakitan dan kematian anak, mengurangi subsidi untuk rumah sakit, dan meningkatkan kualitas generasi penerus bangsa. ${ }^{11}$

Terkait dengan lamanya pemberian ASI, Organisasi Kesehatan Dunia (WHO) menganjurkan kepada para ibu untuk memberikan ASI pada anaknya selama 6 bulan pertama dari kelahirannya, dan dilanjutkan sampai anak berusia 2 tahun dengan pemberian makanan pendamping ASI yang bergizi. Proses ini merupakan kunci bagi tumbuh-kembang sehat optiomal bagi anak. Menurut Al-Maraghi, hikmah ditetapkannya penetapan waktu menyusui bayi dengan masa dua tahun ini adalah, agar kepentingan bayi benarbenar diperhatikan.

Air susu ibu merupakan makanan utama bagi bayi ketika usia itu dan ia sangat membutuhkan kasih sayang dan perawatan ekstra, yang hal ini tidak

11 Nanang Rokhman. (2012). Laktasi dalam Perspektif Al-Qur'an. STIKES Yarsis. hlm. 8 . mungkin dilakukan kecuali oleh ibu kandungnya sendiri. bulan pertama dari kelahirannya, dan dilanjutkan sampai anak berusia 2 tahun dengan pemberian makanan pendamping ASI yang bergizi. Proses ini merupakan kunci bagi tumbuh-kembang sehat optiomal bagi anak. Menurut Al-Maraghi, hikmah ditetapkannya penetapan waktu menyusui bayi dengan masa dua tahun ini adalah, agar kepentingan bayi benarbenar diperhatikan. Air susu ibu merupakan makanan utama bagi bayi ketika usia itu dan ia sangat membutuhkan kasih sayang dan perawatan ekstra, yang hal ini tidak mungkin dilakukan kecuali oleh ibu kandungnya sendiri. ${ }^{12}$

Sayyid Quthb menambahkan, bahwa perintah menyusui selama dua tahun penuh, merupakan waktu yang ideal, baik ditinjau dari kesehatan fisik, jiwa, dan mental spiritual anak. Selain itu, Ibn Jarir Al-Thabari menyatakan, bahwa dua tahun adalah batas maksimal penyusuan untuk semua bayi yang dilahirkan berdasarkan keumuman ayat, sekaligus menjadi pedoman bagi kedua orang tua bayi ketika berselisih tentang waktu menyusui, dan ia menyatakan

\footnotetext{
${ }^{12}$ Nanang Rokhman. (2012). hlm. 8.
} 
bahwa tidak ada penyusuan setelah masa dua tahun.

Muhammad Rasyid Ridha menjelaskan, bahwa perintah menyusui itu wajib secara mutlak. Oleh karena itu, para ibu, baik yang masih sebagai isteri maupun sudah dicerai, wajib menyusui anaknya bila tidak berhalangan seperti sakit dan semacamnya. Begitu pula, kebolehan mencari ibu susu, tidak dapat menghalangi dari kewajiban menyusui. Sebab, kewajiban itu berguna untuk menjaga kebaikan atau kesehatan anak (li al-mashlahah) bukan semata menjalankan perintah Allah (ta'abbud).

Ahmad Mustofa Al-Maraghi menjelaskan, alasan utama diwajibkannya para ibu menyusui anakanaknya adalah karena air susu ibu merupakan makanan terbaik bagi bayi menurut kesepakatan para dokter. Ketika bayi masih dalam kandungan, ia ditumbuhkan dengan darah ibunya. Setelah lahir, darah tersebut berubah menjadi susu yang merupakan makanan utama dan terbaik bagi bayi. Ketika ia telah lahir dan terpisah dari ibunya, maka hanya ASI yang cocok dan paling sesuai dengan perkembangannya.

Abdul Karim Zaidan mengungkapkan, menyusui bayi di samping menjadi kewajiban para ibu, juga merupakan hak mereka. Sebab, ibu adalah orang yang paling berhak menyusui bayi daripada orang lain, selama ia mampu melaksanakannya, baik penyusuan itu dilakukan secara sukarela maupun dengan mendapat upah. Terkait dengan hak ibu untuk menyusui anak yang dilahirkannya, para mufassir telah mengungkapkan pandangannya.

Ibn Jarir Al-Thabari mengatakan, seorang ibu lebih berhak menyusui anaknya daripada orang lain, meskipun tidak disebutkan bahwa Allah mewajibkan kepadanya agar menyusui anak tersebut.

\section{METODOLOGI PENELITIAN}

Metode penelitian dalam pembahasan skripsi ini adalah metode kualitatif yang disajikan sebagai berikut, dimana untuk sumber data maka penulisan ini merujuk kepada kitab tafsir Ibnu Katsir dan adapun sumber data sekunder diambil dari beberapa buku di antaranya; Kedudukan dan Peran Perempuan (Tafsir AlQur'an Tematik) karya Lajnah Pentashihan Mushaf Al-Qur'an, Badan Litbang dan Diklat Kementrian Agama RI. Tafsir Ilmi "Penciptaan Manusia" (Dalam Perspektif Al-Quran dan Sains) karya Lajnah Pentashihan Mushaf Al- 
Qur'an, Badan Litbang dan Diklat Kementrian Agama RI dengan Lembaga Ilmu Pengetahuan Indonesia (LIPI).

Jenis penelitian ini adalah penelitian pustaka, maka metode pengumpulan data yang lebih tepat adalah dengan menggunakan metode dokumentasi. Metode atau teknik pengumpulan data dan informasi melalui pencarian dan penemuan buktibukti. Metode dokumentasi ini merupakan metode pengumpulan data yang berasal dari sumber non manusia. ${ }^{13}$ Data tersebut berupa catatan atau tulisan atau jurnal, dan sebagainya yang diperoleh dari sumber data primer dan sekunder. Dalam hal ini peneliti mengumpulkan teori-teori tentang konsep ibu menyusui dari berbagai literatur terutama dari sumber primer, sekunder dan data-data lain yang mempunyai kaitannya dengan permasalahan yang akan dibahas dalam kajian ini.

\section{PEMBAHASAN}

\section{Pengertian dan Ayat-ayat Tentang Ar-Rada'ah}

Secara etimologis ar-rada'ah adalah sebuah istilah bagi isapan susu, baik isapan susu manusia maupun susu

\footnotetext{
${ }^{13}$ Afifuddin dan Beni Ahmad Saebani. (2009). Metode Penelitian Kualitatif. Bandung: Pustaka Setia. hlm. 140-141.
}

binatang. Dalam pengertian etimologis tidak dipersyaratkan bahwa yang disusui itu [ar-radi'] berupa anak kecil [bayi] atau bukan.

Ayat-ayat tentang menyusui (arraḍa'ah) dalam Al-Qur'an terdapat dalam berbagai ragam dan kalimat ini kurang lebih mencapai sekitar 10 ayat dalam 5 surat. Di antaranya Al-Hajj, Surat At-Thalaq, An-Nisa, Al-Baqarah, dan Surat Al-Qasas. Namun konsep arrada'ah dalam Al-Qur'an diuraikan dalam Q.S. Al-Baqarah [2]: 233, Luqman [31]: 14, dan Al-Ahqaf [46]: 15.

Dasar dan dalil yang menjelaskan tentang Ar-Rada'ah dapat kita dapat dalam Al-Qur`an dan Hadits, di antaranya adalah:

a. Q.S. Al-Baqarah [2]: 233:

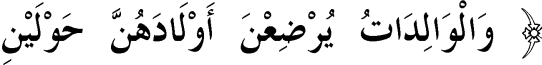

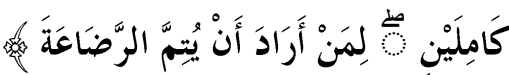

b. Q.S. Luqman [31]: 14:

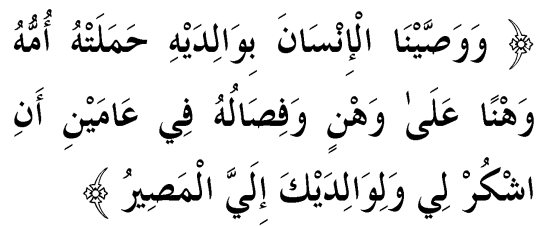

"Dan Kami perintahkan kepada manusia (berbuat baik) 
kepada dua orang ibubapaknya; ibunya telah mengandungnya dalam keadaan lemah yang bertambah-tambah, dan menyapihnya dalam dua tahun. Bersyukurlah kepada-Ku dan kepada dua orang ibu bapakmu, hanya kepada-Kulah kembalimu".

c. Q.S. Al-Ahqaf [46]: 15:

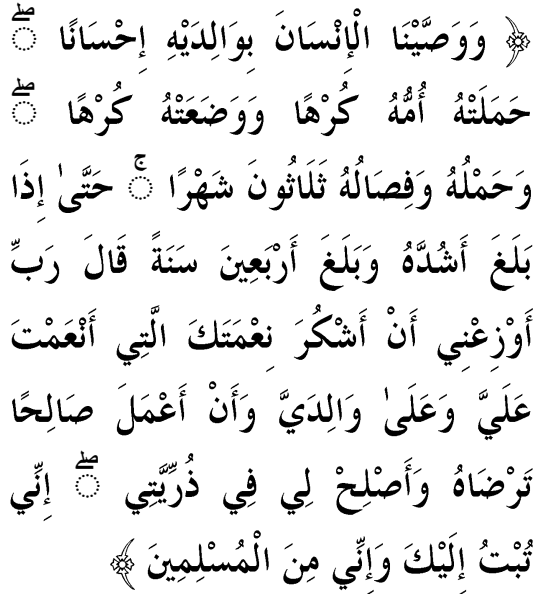

"Kami perintahkan kepada manusia supaya berbuat baik kepada dua orang ibu bapaknya, ibunya mengandungnya dengan susah payah, dan melahirkannya dengan susah payah (pula). Mengandungnya sampai menyapihnya adalah tiga puluh bulan, sehingga apabila dia telah dewasa dan umurnya sampai empat puluh tahun ia berdoa: "Ya Tuhanku, tunjukilah aku untuk mensyukuri nikmat Engkau yang telah Engkau berikan kepadaku dan kepada ibu bapakku dan supaya aku dapat berbuat amal yang saleh yang Engkau ridhai; berilah kebaikan kepadaku dengan (memberi kebaikan) kepada anak cucuku. Sesungguhnya aku bertaubat kepada Engkau dan sesungguhnya aku termasuk orang-orang yang berserah diri".

d. H.R. Al-Bukhari: 550:

Umar bin Khaththab radhiyallahu anhu berkata, "Rasulullah shallallahu 'alaihi wasallam pernah memperoleh beberapa orang tawanan perang. Ternyata dari tawanan tersebut ada seorang perempuan yang biasa menyusui anak kecil. Bila dia mendapati anak kecil dalam tawanan tersebut, dirinya akan mengambil dan menyusuinya. Lalu Nabi Shallallahu alaihi wasallam bersabda kepada kami:

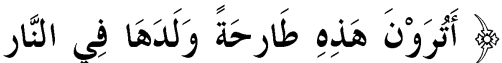

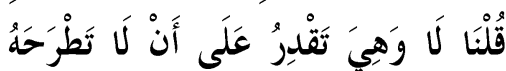

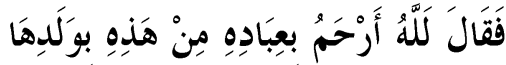

"Menurut kalian, apakah perempuan itu tega melemparkan bayinya ke dalam api?' Kami jawab, 'Sesungguhnya ia tidak akan tega melemparkan anaknya ke dalam api selama masih sanggup menghindarkannya dari api tersebut.' Lalu beliau bersabda, 'Sungguh, kasih sayang Allah terhadap hambaNya melebihi kasih sayang perempuan itu terhadap anaknya".

e. H.R. Ibnu Majah: 1934 


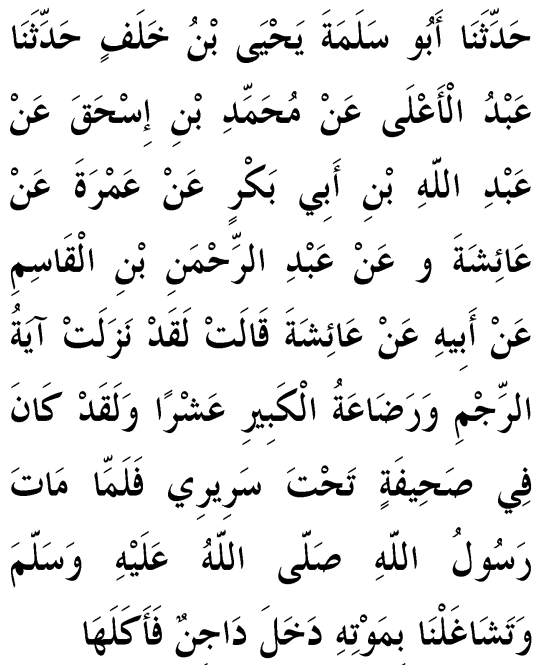

"Abdurrahman Ibnul Qasim dari Bapaknya dari 'Aisyah ia berkata, "Telah turun ayat berkenaan hukum rajam, dan ayat persusuan orang yang telah dewasa itu sebanyak sepuluh kali. Lembaran ayat itu ada di bawah kasurku, ketika Rasulullah shallallahu 'alaihi wasallam wafat kami tersibukkan dengan jasad beliau hingga burung-burung masuk dan memakannya".

\section{Konsep Ar-Rada'ah dalam Al- Qur’an}

Ayat Q.S. Al-Baqarah: [2]: 233 dan Luqman [31]: 14 jelas menyebutkan bahwa dua tahun adalah lama waktu yang disarankan kepada ibu untuk menyusui bayinya. Pada ayat selanjutnya Q.S. Al-Ahqaf [46]: 15 disebutkan bahwa jumlah total masa dalam kandungan dan masa menyusui bayinya adalah 30 bulan. Apabila usia kandungan adalah sembilan bulan maka masa pemberian ASI ekslusif sebaiknya adalah 21 bulan. Bila ketiga ayat ini kita gabungkan dengan sedikit bantuan hitungan matematis maka akan diperoleh angka antara tujuh hingga sembilan bulan masa kehamilan yang normal. ${ }^{14}$ As-Suddi dan adh-Dhahhak berpendapat bahwa ayat QS. AlBaqarah: [2]: 233 berkenaan dengan seorang perempuan yang diceraikan oleh suaminya, semenetara dia memiliki anak dari bekas suaminya itu yang masih berusia dibawah 2 tahun. Seorang perempuan tersebut masih berkewajiban menyusui anaknya meskipun telah bercerai dari suaminya. Seorang ibu tidak boleh kehilangan rasa kasih sayang kepada anaknya sehingga rela anaknya disusui oleh sapi, kambing atau keledai. Ayat ini mengisyaratkan menyusui selama dua tahun merupakan kesempurnaan dalam penyusuan. ${ }^{15}$

Ayat Q.S. Al-Baqarah [2]: 233 terdapat kewajiban kedua orang tua mensejahterakan anak, terutama dalam memenuhi kebutuhan jasmani anak yang terkandung dalam Q.S. AlBaqarah: [2]: 233 di antaranya: a.)

\footnotetext{
${ }^{14}$ Lajnah Pentashihan Mushaf Al-Qur'an. et al. (2012). Penciptaan Manusia dalam Perspektif Al-Qur'an dan Sains. Jakarta: Kementrian Agama RI. hlm. 98.

${ }^{15}$ Imtihan Al-Syafi'i. (2009). Tafsir AyatAyat Wanita: Penjelasan Hukum-Hukum Kewanitaan dalam Al-Qur'an. Solo: Aqwam. hlm. 17.
} 
Kewajiban mendidik anak, b)

Memenuhi kebutuhan anak, c) seorang ibu menyusui anaknya dengan masa penyempurnaannya selama 2 tahun, d) kewajiban seorang ayah memberi nafkah kepada anak dan isterinya dengan cara yang baik dan halal. Kandungan surat tersebut berisi tentang kesejahteraan anak secara jasmani yang harus dipenuhi oleh orang tuanya dengan cara yang makruf. Selain mendapatkan kebutuhan jasmani anak, anak juga mendapatkan kebutuhan secara rohani ketika anak menyusu ibunya makan akan timbul rasa rohani anak antara ibu dan anak dengan curahan kasih sayang saat menyusui anaknya. Kebutuhan terpenting jasmani anak untuk kelangsungan hidup agar anak mampu tumbuh dan berkembang sesuai fitrah yang dianugrahkan Allah Subhanahu Wata"ala pada dirinya. Dengan demikian kewajiban yang Allah Subhanahu Wata"ala berikan kepada orang tua yang terdapat dalam kandungan ayat tersebut, menjelaskan betapa pentingnya kebutuhan fisik (jasmani anak). Jika kebutuhan jasmani terpenuhi maka anak merasa bahagia karena, kesejahteraan jasmaninya terpenuhidengan baik dari orang tuanya diantaranya: kewajiban seorang ibu menyusui anak hingga batas yang paling sempurna 2 tahun dan seorang ayah menafkahi anak dengan cara yang baik.

Pemenuhan kebutuhan yang terkandung dalam Q.S. Al-Baqarah: [2]: 233 sesuai dengan Undang-Undang Kesejahteraan Anak dan Perlindungan Anak, bahwa tata kehidupan dan penghidupan yang dapat menjamin pertumbuhan dan perkembangan dengan wajar dan baik secara rohani, jasmani, dan sosialnya serta segala kegiatan untuk menjamin, melindungi memenuhi hak-hak anak agar dapat hidup serta mendapat perlindungan dari kekerasan dan diskriminasi. Al-Qur'an sangat istimewa karena Al-Qur'an telah mendahului zaman dimana setia ayat Al-Qur'an ternyata mampu menjawab tantangan hidup manusia, terlihat dari kandungan Surat Q.S. Al-Baqarah: [2]: 233 memberikan penjelasan pentingnya kesejahteraan anak dari segi jasmani, sosial dan rohani, yang paling terpenting adalah kesejahteraan jasmani anak. $^{16}$

\section{Konsep Ar-Radha'ah Dalam Tafsir Ibnu Katsir}

16 Arifatul Yuliani. (2013). Konsep Kesejahteraan Anak dalam Al-Qur'an (Kajian Atas Surat Al-Baqarah [2]: 233). Yogyakarta: Fakultas Dakwah dan Komunikas, UIN Sunan Kalijaga. hlm. 98-99. 
Ibnu Katsir mengatakan, dalam Q.S. Al-Baqarah [2]: 233 Hal ini merupakan petunjuk dari Allah Subhanahu Wata"ala kepada para ibu, menganjurkan agar mereka menyusui anak-anak mereka dengan penyusuan yang sempurna, yaitu selama 2 tahun penuh. Sesudah itu penyusuan tidak berpengaruh lagi terhadap kemahraman. Kebanyakan para imam berpendapat bahwa masa penyusuan tidak dapat menjadikan mahram kecuali jika bayi yang disusui berusia di bawah 2 tahun. ${ }^{17}$

Untuk itu seandainya ada anak yang menyusu kepada seorang wanita. Sedangkan usianya di atas 2 tahun, maka penyusuan itu tidak menjadikan mahram baginya. Di dalam bab hadith yang mengatakan bahwa penyusuan tidak menjadikan mahram pada diri seorang anak kecil bila usianya dibawah 2 tahun, Imam At-Tirmidzi mengatakan, telah menceritakan kepada kami Qutaibah, telah menceritakan kepada kami Abu Uwwanah, dari Hisyam ibn Urwah, dari Fatimah binti Munzir, dari Ummu Salamah yang menceritakan bahwa Rasulullah, pernah bersabda: "Tidak akan menjadikan mahram karena susuan, kecuali susuan yang

17 Ibnu Katsir Ad-Dimasyqi. (2000). Tafsir Ibnu Katsir Juz 2 (Al-Baqarah 142-AlBaqarah 252). Bandung: Sinar Baru Algesindo. hlm. 553-554. megenyangkan dan ketika menyusu belum disapih". Hal inilah yang diamalkan dikalangan kebanyakan para ulama dari kalangan sahabat Rasulullah dan lain-lainnya. Dimana mereka berpendapat bahwa penyusuan tidak menjadi mahram kecuali bila dilakukan dalam usia dibawah 2 tahun, sedangkan penyusuan yang dilakukan sesudah usia genap 2 tahun, hal ini tidak menjadi mahram sama sekali. ${ }^{18}$

Pendapat yang mengatakan bahwa persusuan sesudah usia 2 tahun tidak menjadikan mahram diriwayatkan dari Ali, Ibn ‘Abbas, Ibn Mas’ud, Jabir. Abu Hurairah, Ibn Uma, Ummu Salamah, Sa'id Ibn Musayyab, dan Atta serta jumhur ulama. Pendapat inilah yang dipegang oleh Mazhab Syafi'i, Ahmad, Ishak, Ats-Tsauri, Abu Yusuf, Muhammad dan Malik dalam salah satu riwayatnya. Menurut riwayat yang lain dari Imam Malik juga disebutkan bahwa masa persusuan itu adalah 2 tahun 2 bulan dan menurut riwayat yang lainnya lagi yaitu 2 tahun 3 bulan.

Abu Hanifah mengatakan masa penyusuan adalah $2 \frac{1}{2}$ tahun. Zuffar Ibnul Huzail mengatakan bahwa selagi si anak masih mau menyusu, maka

${ }^{18}$ Ibnu Katsir Ad-Dimasyqi. (2000). hlm. 554-555 
batas maksimalnya adalah 3 tahun, pendapat ini merupakan salah satu riwayat dari Al-Auza'i. Malik mengatakan, "Seandainya seorang anak telah dari penyusuan sebelum usia 2 tahun, lalu ada seorang wanita menyusukannya setelah disapih maka penyusuan kali ini tidak menjadikan mahram karena penyusuan saat itu disamakan kedudukannya dengan makanan. Pendapat ini merupakan satu riwayat lai dari Al-Auza'i. Telah diriwayatkan dari Umar dan Ali bahwa keduanya pernah mengatakan, "Tiada persusuan sesudah penyapihan". Maka kalimat ini diinterpretasikan bahwa keduanya bermaksud usia 2 tahun, sama halnya dengan pendapat jumhur ulama, yakni baik telah disapih ataupun belum. Akan tetapi, dapat pula diinterpretasikan bahwa keduanya bermaksud kenyataanya. Dengan demikian, berarti sama denga apa yang diaktan oleh Imam Malik. ${ }^{19}$

\section{Kemukjizatan Ilmiah Ar-Rada'ah bagi Ibu dan Bayi}

Di antara keistimewaan ASI adalah melindungi bayi dari bahaya penyakit karena ia mengandung zat antibodi. Pada hari-hari pertama setelah melahirkan, tubuh ibu kakan 557. mengeluarkan ASI yang mengandung zat kolostrum. Di dalam zat ini terdapat sejumlah besar antibodi yang sangat efektif untuk melindungi bayi dari berbagai penyakit. Semakin lama masa menyusui bayi semakin kuat pula zat antibodi dalam tubuhnya. Hal ini menunjukkan pentingnya ibu menyusui anaknya selama 2 tahun penuh seperti dalam Q.S. Luqman [31]: $14 .^{20}$

ASI sangat diperlukan untuk pertumbuhan dan perkembangan kecerdasan anak. Menurut penelitian, anak-anak yang tidak diberi ASI mempunyai IQ (intelectual quotient) lebih rendah 7-8 poin dibandingkan dengan anak-anak yang diberi ASI secara eksklusif. ASI merupakan makanan bayi yang paling sempurna, mudah dicerna dan diserap karena mengandung enzim pencernaan, dapat mencegah terjadinya penyakit infeksi karena mengandung zat penangkal penyakit seperti immunoglobulin, praktis dan mudah memberikannya serta murah dan bersih. Selain itu, ASI mengandung rangkaian asam lemak tak jenuh yang sangat penting dalam

\footnotetext{
20 Harun Yahya. (2012). Ensiklopedia Mukjizat Ilmiah Al-Qur'an, Keajaiban Penciptaan (Fakta Sains Modern atas AyatAyat Al-Qur'an). Bandung: Sygma Creative Media Corp. hlm. 116-117.
} 
pertumbuhan dan perkembangan otak anak. $^{21}$

Dr. Abdul Muhsin Shalih dalam studinya mengenai ASI menemukan bahwa susu ini memberikan kontribusi yang besar terhadap pembentukan tubuh, akal dan perilaku anak karena anak (bayi) dipengaruhi oleh susu yang dikonsumsinya pada awal kehidupannya, yakni saat ia berada dalam fase pembentukan dan pembangunan tubuh dan akal. Telah ditetapkan secara ilmiah tentang pentingnya ASI dalam menjaga anak dari serangan tekanan darah tinggi karena kesesuaian susunan ASI dengan kebutuhan anak dan rendahnya kadar garam sodium dalam ASI. ${ }^{22}$

Selain pada anak, pemberian ASI juga sangat bermanfaat bagi ibu. Selain dapat diberikan dengan cara mudah dan murah, ASI juga dapat mencegah terjadinya pendarahan setelah persalinan, mempercepat mengecilnya rahim, menunda masa subur, mengurangi anemia, serta menunda terjadinya kehamilan berikutnya. Menyusi juga dapat menurunkan resiko

\footnotetext{
${ }^{21}$ Nurheti Yuliarti. (2010). Keajaiban ASI: Makanan Terbaik untuk Kesehatan, Kecerdasan, dan Kelincahan Si Kecil. hlm. 8. 22 Yusuf Al-Hajj Ahmad. (2009). Ensiklopedi Kemukjizatan Ilmiah dalam AlQur"an dan As-Sunnah. Jakarta Pusat: PT Kharisma Ilmu. hlm. 60.
}

terjadinya kanker payudara dan kanker ovarium pada ibu dikemudian hari.

Pada tahun 2000 penelitian di enam negara berkembang yang melibatkan 147 orang ibu menunjukkan bahwa minimal 20\% ibu yang menyusui akan terhindar dari kanker payudara. Semakin lama ibu tersebut menyusui maka semakin sedikit resiko terserang kanker payudara. Hal lain jauh lebih penting adalah timbulnua ikatan batin yang kuat antara ibu dan anak. Ibu juga tidak perlu susah-susah melakukan diet untuk mengecilkan perut setelah melahirkan karena isapan anak pada puting susu ibu merangsang keluarnya hormon dari kelenjar pituitari (pituitary gland) yang dinamakan dengan hormon oksitosin (oxytocin). Hormon ini berperan dalam penciutan dan pengembalian rahim ke kondisinya semula seperti sebelum hamil. ${ }^{23}$ Ibu yang menyusui juga memiliki keuntungan badannya akan kembali normal dengan cepat. Faktor yang membuat perubahan di badan dan di payudara adalah kehamilan bukan menyusui. $^{24}$

\footnotetext{
60.

${ }^{23}$ Yusuf Al-Hajj Ahmad. (2009). hlm.

${ }^{24}$ Nurheti Yuliarti. (2010). hlm. 11-12.
} 


\section{KESIMPULAN}

Berdasarkan penilitian yang dilakukan oleh penulis maka tentang tema ASI dalam perspektif Al-Quran maka dapat disimpulkan sebagai berikut:

1. Ayat Q.S. Al-Baqarah: [2]: 233 dan Luqman [31]: 14 menyebutkan bahwa dua tahun adalah lama waktu yang disarankan kepada ibu untuk menyusui bayinya. Pada ayat selanjutnya Q.S. Al-Ahqaf [46]: 15 disebutkan bahwa jumlah total masa dalam kandungan dan masa menyusui bayinya adalah 30 bulan. Apabila usia kandungan adalah 9 bulan maka masa pemberian ASI ekslusif sebaiknya adalah 21 bulan.

2. Ayat Q.S. Al-Baqarah: [2]: 233 terdapat kewajiban kedua orang tua mensejahterakan anak, terutama dalam memenuhi kebutuhan jasmani anak yang terkandung di dalam salah satunya ibu menyusui anaknya dengan masa penyempurnaannya selama 2 tahun, kewajiban seorang ayah memberi nafkah kepada anak dan isterinya dengan cara yang baik dan halal.

3. Konsep ar-rada'ah menurut Ibn Katsir Rahimahullah merupakan petunjuk dari Allah Subhanahu Wata'ala kepada para ibu, menganjurkan agar mereka menyusui anak-anak mereka dengan penyusuan yang sempurna, yaitu selama 2 tahun penuh. Sesudah itu penyusuan tidak berpengaruh lagi terhadap kemahraman. apabila pihak ayah dan ibu si bayi sepakat untuk menyapih anaknya sebelum si anak berusia 2 tahun dan keduanya memandang bahwa keputusan inilah yang mengandung maslahat bagi diri bayi, serta keduanya bermusyawarah terlebih dahulu untuk itu dan membuahkan kesepakatan, maka tidak ada dosa atas keduanya untuk melakukan hal tersebut.

4. Keistimewaan ASI adalah melindungi bayi dari bahaya penyakit karena ia mengandung zat antibodi. Di dalam zat ini terdapat sejumlah besar antibodi yang sangat efektif untuk melindungi bayi dari berbagai penyakit. Pemberian ASI juga sangat bermanfaat bagi ibu. Selain dapat diberikan dengan cara mudah dan murah, ASI juga dapat mencegah terjadinya pendarahan setelah persalinan, mempercepat 
mengecilnya rahim, menunda masa subur, mengurangi anemia, serta menunda terjadinya kehamilan berikutnya. Menyusi juga dapat menurunkan resiko terjadinya kanker payudara dan kanker ovarium pada ibu di kemudian hari.

\section{DAFTAR PUSTAKA}

\section{Refrensi dari Jurnal}

Yuliani, A. (2013). Konsep Kesejahteraan Anak dalam AlQur'an (Kajian Atas Surat AlBaqarah [2]: 233). Yogyakarta: Fakultas Dakwah dan Komunikas, UIN Sunan Kalijaga.

\section{Refrensi dari Buku}

Afifuddin dan Saebani, B.A. (2009). Metode Penelitian Kualitatif, Pustaka Setia: Bandung. hlm: 140141

Al-Azzazi, A.Y. (2008). Saat Ibu Mengandung. Surakarta: Ziyad Books.

Al-Hajj, A.Y. (2009). Ensiklopedi Kemukjizatan Ilmiah dalam AlQur'an dan As-Sunnah. Jakarta Pusat: PT Kharisma Ilmu.

Al-Suwailim, W.A. (2013). Fikih Ummahat (Himpunan Hukum Islam Khusus Ibu). Jakarta Timur: Ummul Qura.

Al-Syafiei, I. (2009). Tafsir Ayat-Ayat Wanita Penjelasan Hukum-Hukum
Kewanitaan dalam Al-Qur'an. Solo: Aqwam.

Fadhila, S.R. et., all. (2016). Dampak dari Tidak Menyusui di Indonesia. Jakarta: Ikatan Dokter Anak Indonesia: Indonesian Pediatric Society; Commited in Improving the Health of Indonesian Children.

Katsir, I. (2000). Tafsir Ibnu Katsir Juz 2 (Al-Baqarah 142- Al-Baqarah 252). Bandung: Sinar Baru Algesindo.

Kemenkes. (2015). Dukung Ibu Bekerja Beri ASI Eksklusif. Jakarta.

Lajnah Pentashihan Mushaf Al-Qurean. et all. (2012). Penciptaan Manusia dalam Perspektif Al-Qur'an dan Sains. Jakarta: Kementrian Agama RI.

W.H.O. (1998). Complementary Feeding of young children in developing countries: a review of current scientific knowledge. Geneva: WHO.

Riskesdas. (2016). Situasi Balita Pendek. KemenKes RI.

Rokhman, N. (2012). Laktasi dalam Perspektif Al-Qur"an. STIKES Yarsis.

Yahya, H. (2012). Ensiklopedia Mukjizat Ilmiah Al-Qur"an, Keajaiban Penciptaan (Fakta Sains Modern atas Ayat-Ayat AlQur'an). Bandung: Sygma Creative Media Corp.

Yuliarti, N. (2010). Keajaiban ASI: Makanan Terbaik untuk Kesehatan, Kecerdasan dan Kelincahan Si Kecil. 